\title{
SEASON OF THE YEAR ON YIELDS OF SEVEN MEDIUM-GRAIN VARIETIES OF RICE ${ }^{1,2}$
}

\author{
José M. Lozano and Fernando Abruña ${ }^{3}$
}

\begin{abstract}
The yield of seven medium-grain rice varieties was determined in bimonthly plantings at Gurabo. Chontalpa 16, Brazos, and Vista were the highest yielding varieties averaging $5,700 \mathrm{~kg}$ of rough rice/ha, but yields of Brazos varied more with season of the year. Yields were highest for February plantings and lowest for October plantings, followed by those for August. Similar yields for all seven varieties averaging about $5,100 \mathrm{~kg} / \mathrm{ha}$, were produced when the rice was planted in April, June or December. Varieties and season of the year affected the time required from planting to harvest, which averaged from 101 to 125 days. Lodging was most prevalent in the August plantings, averaging $34 \%$. Nato and Saturn were the most prone to lodging, averaging 21 and $43 \%$, respectively.
\end{abstract}

\section{INTRODUCTION}

Puerto Rico consumes around 180,000 metric tons of rice yearly, about $65 \%$ of which is short grain, $25 \%$ medium grain, and $10 \%$ long grain. Consumption of medium grain rice has increased considerably during the last 2 years.

The effect of planting season on yields of short and long grain varieties of rice has been studied in Puerto Rico, but little work has been conducted with medium grain varieties. Abruña and Lozano found that season did not appreciably affect yields of long grain varieties ${ }^{4}$ and Lozano and Abruña found that for short grain varieties yields were highest for June plantings and lowest for September plantings. ${ }^{5}$ Abruña and Lozano ${ }^{6}$ found that medium grain varieties, especially Vista and Brazos, are more drought tolerant than the short grain varieties tested.

The present study determined the effect of season on productivity of seven medium-grain rice varieties for bimonthly plantings over a 2-year period at Gurabo.

${ }^{3}$ Manuscript submitted to Editorial Board February 2, 1981.

${ }^{2}$ This paper covers work carried out cooperatively between Agricultural Research, Science and Education Administration, USDA, and the Agricultural Experiment Station, College of Agricultural Sciences, Mayagüez Campus, University of Puerto Rico, Río Piedras, PR.

${ }^{3}$ Research Assistant, Agricultural Experiment Station, College of Agricultural Sciences, Mayagüez Campus, University of Puerto Rico; and Soil Scientist, Agricultural Research, Science and Education Administration, USDA.

${ }^{4}$ Abruña, F. and Lozano, J., 1974. Effect of season of the year on yields of 13 varieties of rice growing in the humid region of Puerto Rico, J. Agric. Univ. P.R. 58 (1):11-17.

${ }^{5}$ Lozano, J. and Abruña, F., 1977. Effect of planting season on yields of eight short-grain varieties of rice under irrigation, J. Agric. Univ. P.R. 61 (1):6-10.

${ }^{6}$ Abruña, F. and Lozano, J., 1977. Productivity of 25 varieties of rice grown under conditions of limited moisture, J. Agric. Univ. P.R. 61 (1):1-5. 


\section{MATERIALS AND METHODS}

The experiment was conducted at the Gurabo Substation of the Agricultural Experiment Station, located about $80 \mathrm{~m}$ above sea level and with a mean annual temperature of $27^{\circ} \mathrm{C}$. The soil is Coloso clay (Aeric Tropic Fluvaquents) with an organic matter content of $2.3 \%, \mathrm{a} \mathrm{pH}$ of 6.6 , and a cation exchange capacity of $21 \mathrm{meq} / 100 \mathrm{~g}$ of soil.

Seven medium grain rice varieties were tested. Vista, Nato and Saturn are commercial varieties, extensively planted in the southern United States. Brazos ${ }^{7}$ has a very high yield potential. Chontalpa 16, developed in Mexico, has a high yield potential as well as disease resistance. Sequial, developed in Spain, is early maturing and resistant to lodging ${ }^{8}$. B.M.T. (RU 7403025) is an experimental selection from the breeding program in Beaumont, Texas.

All varieties were planted about mid-month during February, April, June, August, October and December for two consecutive years (1978 and 1979).

Plots were $4 \times 4 \mathrm{~m}$, replicated five times, and arranged in a randomized block design. The experimental area was surrounded by levees and permanently flooded, starting about 3 weeks after seeding.

Seed of the different varieties was broadcast at a rate of $110 \mathrm{~kg} / \mathrm{ha}$ and covered with about $2 \mathrm{~cm}$ of soil by hand raking. All plots were fertilized at the rate of $60 \mathrm{~kg}$ of $\mathrm{N}, 25 \mathrm{~kg}$ of $\mathrm{P}$, and $40 \mathrm{~kg}$ of $\mathrm{K} / \mathrm{ha} 2$ weeks after germination and again about 40 days after seeding. Weeds were controlled with Propanil ${ }^{9}$ at the rate of $151 / \mathrm{ha}$. Insects and diseases were controlled by periodic spraying with pesticides approved by EPA. Rats were controlled with poison bait.

The rice was harvested at about $20 \%$ moisture, threshed and dried to $12 \%$ moisture; and yield determined.

\section{RESULTS AND DISCUSSIONS}

Table 1 shows that yield differences among varieties as well as planting seasons were significant. Chontalpa 16, Brazos and Vista produced the highest overall yields, averaging $5,700 \mathrm{~kg} / \mathrm{ha}$ of rough rice, followed by Nato, Sequial and B.M.T., averaging $4,500 \mathrm{~kg} / \mathrm{ha}$; and Saturn averaging only $4,000 \mathrm{~kg} / \mathrm{ha}$. Chontalpa 16 was among the highest yielding for five of the six plantings, and Brazos and Vista for four.

${ }^{7}$ Bollich, C. N., Scott, J. E., Webb, B. D., and Atkins, J. G., 1974. New high yield medium-grain variety released in Texas, The Rice Jan. Vol. 77 No. 3.

${ }^{8}$ López-Campos, G., Ballesteros, R., Castells, J. and Batalla, J. A., 1970. Variedades de arroz cultivadas en España, Estación Arrocera (I.N.I.A.) Publicado por Federación Sindical de Agricultores Arroceros, Valencia, España.

${ }^{9}$ Trade names in this publication are used only to provide specific information. Mention of a trade name does not constitute a warranty of equipment or materials by the Agricultural Experiment Station of the University of Puerto Rico, nor is this mention a statement of preference over other equipment or materials. 
Planting season had a marked effect on grain yields, which generally decreased steadily from February to October. Highest monthly yields were produced in the February plantings, followed by those in April and December, which averaged $5,330 \mathrm{~kg} / \mathrm{ha}$. The October planting produced the lowest yields.

Of the three highest yielding varieties, yields of Brazos varied most with season of the year (fig. 1). Chontalpa 16 produced the highest yields $(5,190 \mathrm{~kg} / \mathrm{ha})$ in the October plantings, when yields of all other varieties decreased sharply.

Figure 2 shows the average monthly daylength and rainfall during the experiments. During the growing season, ( 1 to 3 months after planting) for rice planted in December and February, sunlight was sufficient for the production of high yields because even though days were rather short,

TABLE 1.-Effect of planting season on monthly and yearly yields of seven medium grain rice varieties at Gurabo, Puerto Rico

\begin{tabular}{lccccccc}
\hline \multirow{2}{*}{ Variety } & \multicolumn{7}{c}{$\mathrm{Kg} / \mathrm{ha}$ of rough rice planted in } \\
\cline { 2 - 8 } & February & April & June & August & October & December & $\begin{array}{c}\text { Variety } \\
\text { average }\end{array}$ \\
\hline Vista & $6,350 \mathrm{~b}, \mathrm{c}^{\mathrm{1}}$ & $5,830 \mathrm{a}, \mathrm{b}, \mathrm{c}$ & $5,460 \mathrm{a}, \mathrm{b}$ & $4,790 \mathrm{a}$ & $4,520 \mathrm{~b}$ & $6,590 \mathrm{a}, \mathrm{b}$ & $5,590 \mathrm{a}$ \\
Brazos & $6,980 \mathrm{a}, \mathrm{b}$ & $6,530 \mathrm{a}$ & $5,900 \mathrm{a}$ & $5,030 \mathrm{a}$ & $3,080 \mathrm{~d}, \mathrm{e}$ & $5,850 \mathrm{~b}$ & $5,569 \mathrm{a}$ \\
Nato & $6,040 \mathrm{c}$ & $5,340 \mathrm{~b}, \mathrm{c}$ & $4,940 \mathrm{c}, \mathrm{b}$ & $4,700 \mathrm{a}$ & $2,650 \mathrm{e}, \mathrm{f}$ & $3,810 \mathrm{c}$ & $4,580 \mathrm{~b}$ \\
Saturn & $6,690 \mathrm{a}, \mathrm{b}, \mathrm{c}$ & $4,380 \mathrm{~d}$ & $4,400 \mathrm{c}$ & $3,910 \mathrm{~b}$ & $2,080 \mathrm{f}$ & $2,520 \mathrm{~d}$ & $3,997 \mathrm{c}$ \\
Chontalpa 16 & $7,470 \mathrm{a}$ & $6,120 \mathrm{a}, \mathrm{b}$ & $4,940 \mathrm{c}, \mathrm{b}$ & $5,080 \mathrm{a}$ & $5,190 \mathrm{a}$ & $6,940 \mathrm{a}$ & $5,958 \mathrm{a}$ \\
Sequial & $5,190 \mathrm{~d}$ & $4,810 \mathrm{c}, \mathrm{d}$ & $4,670 \mathrm{c}$ & $3,040 \mathrm{c}$ & $3,350 \mathrm{c}, \mathrm{d}$ & $5,970 \mathrm{~b}$ & $4,505 \mathrm{~b}$ \\
$\begin{array}{l}\text { B.M.T. (RU } \\
\quad 7403025)\end{array}$ & $4,080 \mathrm{e}$ & $5,370 \mathrm{~b}, \mathrm{c}$ & $4,840 \mathrm{c}$ & $4,000 \mathrm{~b}$ & $3,810 \mathrm{c}$ & $4,550 \mathrm{c}$ & $4,442 \mathrm{~b}$ \\
$\quad$ & & & & & & & \\
Monthly av- & $6,114 \mathrm{a}$ & $5,484 \mathrm{~b}, \mathrm{c}$ & $5,021 \mathrm{~b}, \mathrm{c}, \mathrm{d}$ & $4,364 \mathrm{~d}$ & $3,526 \mathrm{e}$ & $5,176 \mathrm{~b}, \mathrm{c}$ & 4,948 \\
$\quad$ erage & & & & & & & \\
\hline
\end{tabular}

${ }^{1}$ Values in columns with one or more letters in common do not differ statistically (Duncan multiple range).

there was little cloudiness; rainfall during this period was low (fig. 2). During the growth period of the April and June plantings, the days were cloudy but long, with sufficient light for the production of high rice yields. However, during August and especially the October growing period, days were becoming shorter and were cloudy, so yields were low (fig. 1 and 2), probably as a result of insufficient light; although high rainfall may also have affected yields in other ways, such as reducing flower set.

Table 2 shows that the number of days required from planting to harvest varied with planting season and with varieties. The Sequial variety was the earliest maturing, requiring only an average of 102 days from seeding to harvest, and ranging in growing season from 89 days for the August planting to 120 days for the December planting. Chontalpa 16 was the latest maturing, requiring an average of 122 days. Except for the 


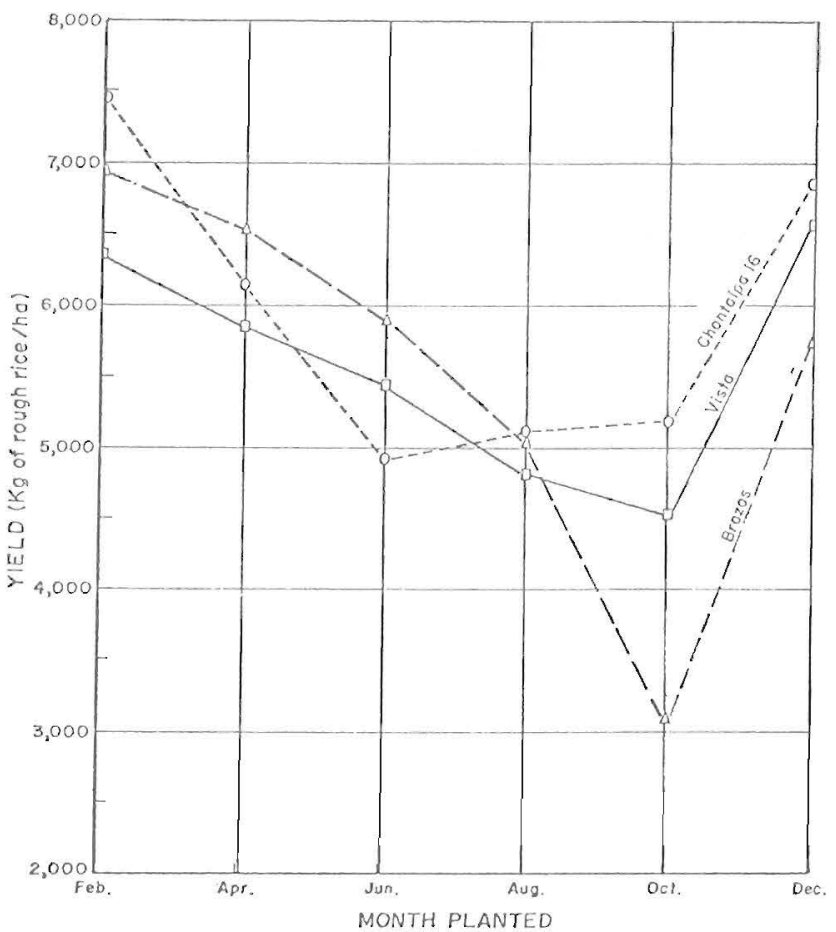

FiG. 1.-Effect of season of the year on yields of the three highest yielding medium grain rice varieties at Gurabo. All values are average of 2 years (1978 and 1979).

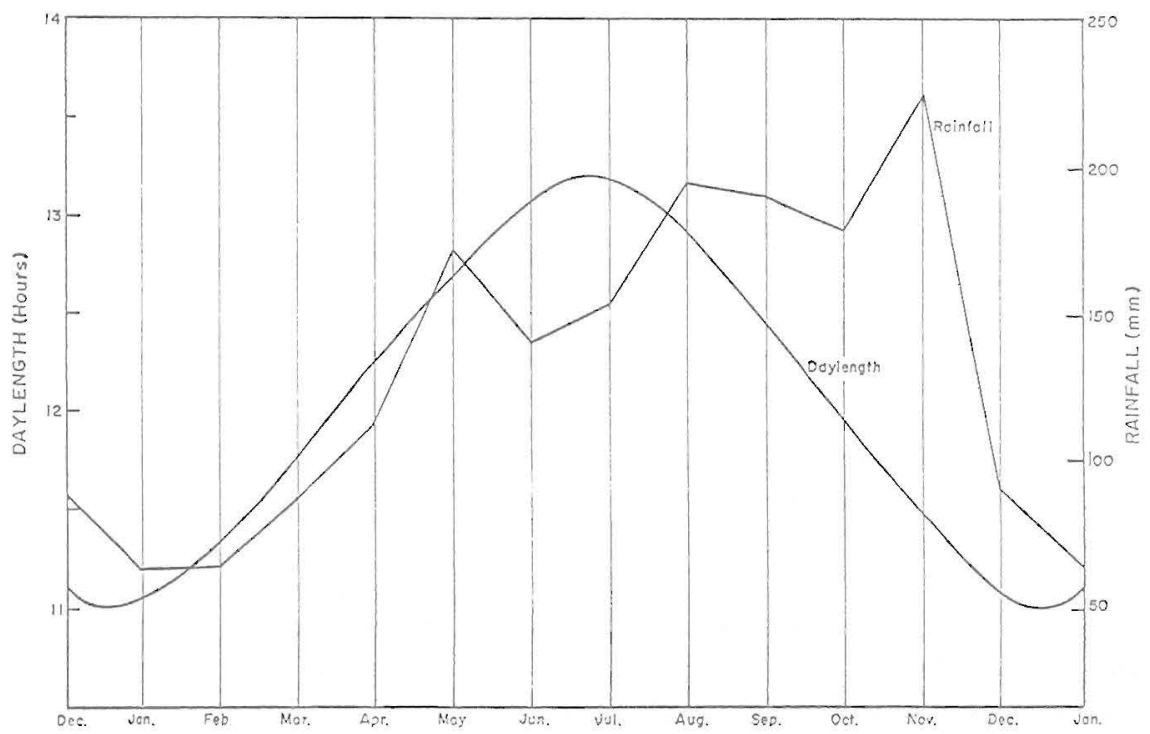

FIG. 2.-Average monthly day length and rainfall for 1978 and 1979 at Gurabo. 
December plantings, the U.S. varieties generally produced a crop within a considerably shorter period in Puerto Rico than they do in Louisiana, Texas or Arkansas, where most of these varieties were developed.

The April to August plantings were the earliest maturing, and the December planting was the latest.

Table 3 shows that the varieties tested varied considerably in their susceptibility to lodging. Saturn was by far the most susceptible to

TABLE 2.-Effect of planting season on number of days from planting to harvest of seven medium grain rice varieties growing at Gurabo

\begin{tabular}{lcrrrrrr}
\hline \multirow{2}{*}{ Variety } & \multicolumn{6}{c}{ Number of days from planting to harvest for rice planted in } \\
\cline { 2 - 8 } & February & April & June & August & October & December & $\begin{array}{c}\text { Yearly av- } \\
\text { erage }\end{array}$ \\
\hline Vista & 108 & 100 & 99 & 101 & 117 & 122 & 108 \\
Brazos & 115 & 110 & 107 & 103 & 120 & 128 & 114 \\
Nato & 114 & 108 & 107 & 103 & 116 & 129 & 113 \\
Saturn & 117 & 112 & 100 & 104 & 118 & 126 & 113 \\
Chontalpa 16 & 136 & 127 & 118 & 110 & 116 & 126 & 122 \\
Sequial & 103 & 98 & 98 & 89 & 102 & 120 & 102 \\
B.M.T. (RU & 104 & 96 & 100 & 98 & 114 & 126 & 106 \\
$\quad$ 7403025) & 114 & 107 & 104 & 101 & 115 & 125 & - \\
Averages & & & & & & & \\
\hline
\end{tabular}

TABLE 3.-Effect of planting season on lodging of seven medium grain rice varieties grown at Gurabo

\begin{tabular}{lrrrrrrr}
\hline \multirow{2}{*}{ Variety } & \multicolumn{7}{c}{ Percent lodging in rice planted } \\
\cline { 2 - 8 } & February & April & June & August & October & December & $\begin{array}{c}\text { Yearly av- } \\
\text { erage }\end{array}$ \\
\hline Vista & 0 & 5 & 0 & 20 & 0 & 0 & 4 \\
Brazos & 0 & 30 & 0 & 40 & 0 & 0 & 12 \\
Nato & 25 & 30 & 40 & 30 & 0 & 0 & 21 \\
Saturn & 50 & 45 & 60 & 100 & 0 & 0 & 43 \\
Chontalpa 16 & 5 & 10 & 35 & 30 & 0 & 0 & 13 \\
Sequial & 25 & 0 & 20 & 20 & 0 & 0 & 11 \\
BMT (RU & 0 & 0 & 0 & 0 & 0 & 0 & 0 \\
$\quad$ 7403025) & & & & & & & 0 \\
Monthly average & 15 & 17 & 22 & 34 & 0 & 0 & 0 \\
\hline
\end{tabular}

lodging, followed by Nato. Brazos, Chontalpa 16 and Sequial were similar in their susceptibility to lodging. Vista and BMT were the most resistant to lodging.

None of the varieties in the October and December plantings lodged. However, lodging was more severe in the August plantings. The heavy lodging in the August planting may have been caused by the heavy rainfall and winds during the growing season. 
In addition to average yearly yields, which were similar for the Brazos, Vista and Chontalpa 16 varieties, other factors must be considered in deciding which variety to plant. Yields of Chontalpa 16 varied less seasonally than did the others; Chontalpa 16 is apparently very disease resistant. However, Chontalpa 16 grains did not meet the exacting U.S. quality standards, in terms of cooking quality.

Brazos produced high yields of excellent quality rice during most of the year but yields for fall plantings were very low (fig. 2) and it is more susceptible to blast (Piricularia oryzae) under some conditions. Vista produces good quality rice, is apparently resistant to lodging (table 3 ), and outyielded Brazos in the fall plantings.

\section{RESUMEN}

Por dos años consecutivos, en siembras bimestrales en Gurabo, se investigó el efecto de la época de siembra sobre el rendimiento y comportamiento de siete variedades de arroz de grano intermedio. Las variedades Chontalpa 16, Brazos y Vista fueron superiores en rendimiento a las demás, logrando una producción media de $5,700 \mathrm{~kg} / \mathrm{ha}$ y cosecha. De estas tres variedades, la Brazos fue la que más varió en rendimiento durante el año.

Los mayores rendimientos se lograron en las siembras efectuadas a mediados de febrero, alcanzando un promedio de $6,114 \mathrm{~kg} / \mathrm{ha}$, mientras que las más bajas se registraron en las siembras de octubre con un promedio de sólo $3,526 \mathrm{~kg} / \mathrm{ha}$. Se lograron rendimientos superiores a los $5,000 \mathrm{~kg} / \mathrm{ha}$ en las siembras de febrero, abril, junio y diciembre. La siembra de agosto produjo un rendimiento medio de $4,363 \mathrm{~kg} / \mathrm{ha}$.

Tanto las variedades como la época de siembra afectaron la duración del período de crecimiento. La variedad Sequial requirió un promedio de 102 días desde la siembra hasta la cosecha, mientras que la Chontalpa 16 requirió 122 días. La siembra de agosto requirió un promedio de sólo 101 días, mientras que la siembra de diciembre necesitó 125 días.

La variedad Saturn fue la más sensitiva al encamado, con un promedio de $43 \%$ para todo el año, mientras que las Vista y B.M.T. (RU 7403025) apenas fueron afectadas. El porcentaje mayor de encamado se registró en las siembras de agosto, mientras que en las de octubre y diciembre apenas lo hubo. 